\title{
O expressionismo de Erwartung diante do problema do fetichismo musical
}

\author{
Philippe Curimbaba Freitas (UNESP, São Paulo, SP) \\ pcurimbaba@uol.com.br
}

\begin{abstract}
Resumo: 0 monodrama Erwartung, de Arnold Schoenberg, foi caracterizado por um lado como sintese do expressionismo e, por outro, como uma composição não definível por meio de categorias formais. Esta convergência entre expressão e negação da forma, apontada por Carl Dahlhaus, é o ponto de partida deste texto, cujo objetivo é sustentar, mais do que uma simples convergência, uma relação determinada entre expressão e negação da forma, ou da convenção. Isto é realizado em três momentos: primeiro, desenvolve-se o conceito adorniano de fetichismo musical; segundo, aborda-se a relação entre a expressão e a convenção à luz do problema do fetichismo musical, o que permite aproximar noções como a negação da convenção, a negação romântica do objetivismo musical em prol da expressão subjetiva e a recusa de materiais fetichizados; em terceiro lugar, aborda-se Erwartung, mostrando como o problema da convenção, do objetivismo e do fetichismo não deixam de aparecer em uma peça que leva às últimas consequências a radicalização da expressão pela negação da convenção.
\end{abstract}

Palavras-chave: Arnold Schoenberg; expressionismo musical; forma musical; fetichismo musical.

\section{Erwartung's expressionism facing the problem of musical fetishism}

\begin{abstract}
Arnold Schoenberg's monodrama Erwartung was characterized on one hand, as the epitome of expressionism and, on the other, as a composition not definable by formal categories. This convergence of expression and denial of form, remarked by Carl Dahlhaus, is the starting point of this text, which purpose is to sustain more than a simple convergence, but a well-defined relationship between expression and denial of form and convention. This involves three moments: first, the development of Adorno's concept of musical fetishism; second, the approach to the relationship of expression and convention seen from the perspective of musical fetishism, which enables us to approximate some notions as the denial of convention, the Romantic denial of musical objectivism in favor of subjective expression, and the refusal of fetishized material; and finally, the approach to the Erwartung, showing that the problem of convention, objectivism and fetishism still remains in a piece which leads the radicalization of expression through denial of convention to the ultimate consequences.
\end{abstract}

Keywords: Arnold Schoenberg; expressionism in music; musical form; musical fetishism.

\begin{abstract}
"O espanto que Schoenberg e Webern suscitam, agora como antes, não emana de sua incompreensibilidade, mas do fato de que se entende bem demais. Sua música configura de imediato aquele medo, aquele terror, aquela percepção da situação catastrófica da qual os demais querem se safar, retrocedendo. Chamamos individualistas, quando na realidade sua obra não é mais do que um único diálogo com os poderes que destroem a individualidade - poderes cujas 'deformes sombras' incursionam hipertrofiadas em sua música". (ADORNO, 2009, p.50).
\end{abstract}

\section{1 - Introdução}

A obra musical da Segunda Escola de Viena do período expressionista é frequentemente caracterizada na literatura musicológica pela ruptura com as características estilísticas do passado. Tanto a dissonância emancipada ${ }^{1}$ como a ausência de tema em algumas obras são caracteristicas que abalaram a compreensão musical imediata ao retirarem da música justamente aqueles principais elementos por meio dos quais ela antes se fazia inteligivel. Isto revela uma convergência entre expressão e negação da forma, convergência esta que se exprime por exemplo na literatura sobre o monodrama Erwartung Op.17, de Schoenberg, o qual foi caracterizado 
"de um lado - vista da perspectiva da história do espírito [Geistesgeschichte] - como a sintese do Expressionismo, e de outro lado - vista em termos de história da composição - como a realização da ideia de uma música que é atemática e não definivel por categorias formais" (DAHLHAUS, 1990, p.149).

0 objetivo deste artigo é sustentar mais do que uma simples convergência: uma relação determinada entre o anseio expressionista pela expressão pura, por um lado, e a recusa de elementos formais que tradicionalmente garantiam a inteligibilidade, por outro. Isto é realizado baseando-se, por um lado, no conceito de fetichismo musical desenvolvido por Theodor Adorno e, por outro, em abordagens analíticas já existentes desse monodrama, referentes aos aspectos musicais, isto é, não literários. $A$ escolha dessa obra não é gratuita: trata-se provavelmente da obra que exprime mais nitidamente essa convergência entre expressão e negação dos meios convencionais. Deste modo, pretende-se lançar as bases para uma análise da obra que tenha como foco a articulação entre expressão e fetichismo.

Em primeiro lugar, o texto analisa o conceito de fetichismo musical em três dimensões, abordadas por Adorno, e o caracteriza a partir de um traço essencial que constitui a música fetichizada: a autonomia da totalidade da forma em relação à particularidade dos momentos. Aparentemente tal maneira de pensar a música fetichizada soa como um paradoxo, pois o que de fato parece ocorrer é uma autonomia da parte em relação ao todo. 0 que se buscará é exatamente efetuar este giro por meio do qual a totalidade, para Adorno, migra para as partes. Em segundo lugar, aborda-se a relação entre a expressão e a convenção à luz do problema do fetichismo musical, o que permite aproximar noções como a negação da convenção, a negação romântica do objetivismo musical em prol da expressão subjetiva e a recusa de materiais fetichizados. Em terceiro lugar, são apresentadas e discutidas algumas análises da obra que, abordadas a partir do problema da expressão, permitem compreender a radicalização da expressão em Erwartung como uma tomada de posição radical frente ao problema do fetichismo, isto é, como uma recusa dos materiais fetichizados. Mostra-se também como a simples negação da convenção, do objetivismo e do fetichismo não soluciona o problema da expressão, pois esses três elementos negados voltaram a aparecer na música, ainda que de forma diferente.

\section{2 - Racionalização musical e autonomia da forma}

Adentremos no conceito de fetichismo musical a partir de Max Weber. Em seu Fundamentos Racionais e Sociológicos da Música (WEBER, 1995), o sociólogo desenvolve um conceito central para o diagnóstico adorniano a respeito da música fetichizada: a racionalização musical. Vejamos uma das maneiras como Weber apresenta este conceito:
"Com o desenvolvimento da música a uma 'arte' estamental (...), com o ultrapassamento do emprego meramente prático-

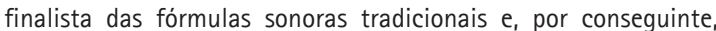
com o despertar das necessidades puramente estéticas, inicia-se regularmente sua verdadeira racionalização" (WEBER, 1995, p.86).

A música se racionaliza ao livrar-se de funções rituais, no interior das quais adquiria poderes mágicos, religiosos, medicinais etc. Os materiais musicais eram nesses contextos determinados a partir fórmulas às quais se atribuía poderes sobrenaturais. Portanto, um dos aspectos da racionalização musical é sua autonomização em relação a funções rituais. Livres da subordinação a tais funções extra-musicais, os materiais musicais passam a ser adotados e desenvolvidos a partir de necessidades puramente musicais. Autônoma em relação aos "fins práticos", a música se realiza em função do "gozo estético" (WAIZBORT, 1995, p.39).

No entanto, a autonomia da música não se esgota, segundo Weber, na liberação em relação aos objetivos prático-finalistas. Mesmo realizada com o objetivo do "gozo estético", a música ainda pode constituir e desenvolver seu material pela mimetização de elementos extra-musicais:

\begin{abstract}
"Em certas circunstâncias, a fala pode ainda exercer (...) uma influência direta e completa sobre a formação do curso da melodia: se esta língua, por exemplo, for uma das chamadas 'línguas sonoras', nas quais o significado das sílabas é variável de acordo com a altura do som em que são pronunciadas." (WEBER, 1995, p.81)
\end{abstract}

Weber comenta em seguida uma série de casos nos quais a música toma as características da fala como um princípio mimético. Em contraposição a isso, racionalização também significa autonomização em relação a qualquer princípio mimético extra-musical no interior da música.

A racionalização da música, para Weber, não é unívoca: pode se dar em diversos graus e direções. Weber descreve e analisa em sua sociologia da música as músicas de diferentes povos, suas características específicas e seus diversos graus e modos de racionalização. 0 que the interessa é determinar aquilo que é específico à música ocidental. Tal especificidade consiste, para Weber, no caráter harmônico da racionalização de intervalos, o que não implica uma recusa dos elementos irracionais, não harmônicos, mas uma subordinação destes à racionalidade harmônica. São irracionais, por exemplo, os intervalos cromáticos, isto é, que não pertencem a uma determinada escala diatônica, os quais são racionalizados ao serem interpretados, no interior de uma harmonia cromática, como fundamental, terça ou quinta de uma tríade, isto é, ao serem harmonizados. Deste modo, os elementos melódicos, ainda irracionais - na medida em que seus intervalos se baseiam no gesto orgânico, mimetizado pela música, e não no sistema de divisão matemática da oitava -, são filtrados no interior de um sistema racional que os assimila e consequentemente os racionaliza, ou seja, os "harmoniza". Além disso, são também irracionais os intervalos da melodia que não aparecem como som de uma 
tríade, isto é, que não são harmonizados: as dissonâncias. Estas, para poderem ocorrer na música racionalizada harmonicamente, são preparadas e resolvidas por consonâncias, ou seja, são subordinadas à consonância, e só assim podem ser legitimadas, ou racionalizadas. Assim, na música harmônica ocidental a razão manteve-se, para Weber, soberana em relação aos elementos irracionais.

A música harmônica ocidental desenvolveu, portanto, um sistema fechado de regras de contraponto e progressões harmônicas que tornou possível que ela absorvesse todo elemento extra-musical, todo resíduo de irracionalidade e de mimetismo sem abrir mão de sua racionalidade; que ela pudesse cifrar todo resíduo irracional no interior de um sistema racional autônomo, isto é que funciona segundo suas próprias leis, as quais não sofrem ação desses resíduos; que ela pudesse "ensimesmar-se em uma construção de regras artísticas cada vez mais sublimada e complexa" (WEBER, 1995, p.109).

Assim, no interior do conceito weberiano de racionalização musical encontramos um diagnóstico de autonomização da forma musical em relação não só aos fins rituais mas também aos materiais melódicos não racionalizados, que mimetizam elementos extramusicais como por exemplo o gesto corporal, a fala ou o texto. Esse conceito de autonomia da forma musical é de importância decisiva para uma discussão sobre 0 fetichismo musical, tal como este foi pensado por Adorno. No entanto é importante frisar que autonomia musical não implica necessariamente fetichismo da música: a relação entre ambos conceitos é bastante complexa. $\mathrm{Na}$ grande música autônoma do classicismo vienense, as "superficialidades", os "estímulos aos sentidos", as melodias "profanas" e todos os elementos irracionais no sentido weberiano são absorvidos e submetidos aos princípios de organização formal do classicismo ou, para continuar com Weber, são racionalizados. Portanto, a autonomia da forma aparece nitidamente como princípio compositivo no classicismo vienense, não obstante Adorno valoriza essa música e de modo algum identifica nela qualquer forma de fetichismo. Pelo contrário:

\footnotetext{
"Na multiplicidade do estímulo e da expressão se demonstra sua grandeza como capacidade de síntese. Não só a síntese musical conserva a unidade da aparência e da vigilia para que não decaia nos difusos instantes do saboroso. Além disso, nesta unidade, na relação dos momentos particulares com a totalidade que se gera, se mantém também a imagem de uma situação social na qual aqueles elementos particulares de felicidade seriam mais do que mera aparência". (ADORNO, 2009, p.18).
}

Adorno se refere à música de Haydn, na qual identifica uma tensão dialética entre parte e todo. A síntese musical supera o caráter efêmero dos "difusos instantes do saboroso", realiza uma crítica dos momentos particulares, impedindo que eles se dissolvam como mera aparência. Isto significa que todos aqueles elementos imediatos que aparecem como "estímulo", "superficialidade" etc. são ligados e resolvidos no interior de uma forma unitária, de modo que as passagens entre eles soam de maneira contínua e necessária, constituindo um todo, quer seja em virtude do trabalho motívico ou temático, quer seja pela relação harmônica coerente, a partir de um princípio harmônico que, no caso do classicismo vienense, consiste basicamente na extensão à peça toda do movimento cadencial sobre a tônica, representado pelo esquema de Réti I-x-V-I, apresentado por Jean-Jacques Nattiez, em que $x$ pode ser igual a zero, ou pode representar desde um único grau até uma longa progressão de acordes. (NATTIEZ, 1984, p.337). Para Adorno, não apenas o todo opera uma crítica das partes como também as partes impõem resistência à hipóstase do todo: a superioridade do "galante" na música de Haydn frente ao "acadêmico" está no fato de que o princípio formal unitário não encontra, em Haydn, sua legitimação em si mesmo mas no confronto com seu oposto, isto é, com os elementos efêmeros, que pretende superar (ADORNO, 2009, p.18). Essa relação tensa entre partes e todo, em que o todo articula e supera as partes e estas impõem resistência ao todo, cristaliza a imagem de uma sociedade na qual "aqueles elementos particulares de felicidade seriam mais do que mera aparência". Nesse impulso à superação do efêmero e das aparências, a música de Haydn realiza, para Adorno, uma reflexão de caráter social, e nisto consistiria seu valor artístico.

\section{3 - As três dimensões do fetichismo musical}

Em oposição ao que ocorre nesses casos do classicismo vienense, na música fetichizada os momentos parciais se isolam do todo e se oferecem em si mesmos como objetos do gozo, dispensando assim o ouvinte a "pensar sobre o todo". 0 ouvinte fetichista não apenas é incapaz de reconstituir o todo a partir dos momentos parciais como tampouco está em condições de compreender tais momentos a partir do sentido que adquirem como função do todo, isto é, ouvem os momentos como se eles se esgotassem em si mesmos. Isto pode levar a crer que, na música fetichizada, a forma abriu mão de sua autonomia em prol dos momentos parciais, cuja imediatez deixou já de censurar. Deste modo, a unidade sintética teria então deixado de se impor frente aos materiais, os quais poderiam então falar por si mesmos, libertando-se da violência do todo, por assim dizer. No entanto, a posição de Adorno não é esta. Em primeiro lugar, o fato de que, na música fetichizada, os momentos parciais são em si mesmos objetos de gozo - já que o gozo não cobra do ouvinte uma consciência das relações entre esses momentos e de cada um deles com o todo não significa que o todo deixou de exercer qualquer papel na organização das partes. A respeito disto vale salientar a importância atribuída por Adorno às repetições e ao clímax na eficácia da música em impregnar-se no ânimo do ouvinte, eficácia esta que se põe a serviço do êxito comercial. (ADORNO, 2009, p.28).

Aqui torna-se necessário destrinchar o diagnóstico adorniano a respeito do fetichismo musical em um triplo diagnóstico, como propõe Vladimir Safatle (SAFATLE, 
2007, p.376), isto é, em um diagnóstico que envolve três dimensões: a dos modos de audição, a da estrutura musical e a da função social.

Iniciemos abordando o fetichismo a partir da dimensão dos modos de audição, isto é, da questão da audição fetichista. 0 ponto central no que se refere aos modos de audição está presente em uma passagem de Adorno bastante elucidativa:

\footnotetext{
"Um especialista norte-americano em anúncios radiofônicos que se serve com preferência do meio musical se manifestou com ceticismo sobre o valor destes anúncios, pois os homens teriam aprendido, inclusive durante a audição, a anular a atenção ao que é ouvido. (...) Sua tese é correta quando se trata da concepção mesma da música" (ADORNO, 2009, p.16)
}

Um elemento central que marca para Adorno a consciência musical fetichista é a ausência de apreciação qualitativa daquilo que se escuta. Se pedese a um ouvinte fetichista que fale sobre alguma música que tenha ouvido ou da qual afirme gostar, o que salta à vista é a absoluta incomensurabilidade entre suas impressões subjetivas e as qualidades objetivas daquilo que escutou. A consciência musical do ouvinte fetichista está a tal ponto distante da música que lhe é impossivel ter uma experiência propriamente musical. As melodias são experimentadas pelo ouvinte como algo carente de determinações musicais, algo que se possa agarrar na sua imediatez, como imediatamente pleno de sentido e que o compositor imprime na obra como algo próprio de si que está para além das qualidades objetivas da música: como "inspiração do compositor, a quem se pretende poder levar para casa em propriedade, de igual modo que a inspiração se atribui ao compositor como sua propriedade raiz" (ADORNO, 2009, p.22). Não apenas os elementos de "inspiração", como também a voz dos cantores e o som dos instrumentos musicais são apreendidos isoladamente pelo ouvinte fetichista, desprovidos de qualquer função musical. Tendo perdido toda relação objetiva com a música, resta explicar como esta passa a se relacionar com esse ouvinte. É o que Adorno faz na seguinte passagem:

\footnotetext{
"Se convertem-se em fetiches os momentos de estimulação sensual da inspiração, da voz, do instrumento, e estes se dissociam de todas as funções que Ihes poderiam dar sentido, então respondem desde o mesmo isolamento emoções cegas e irracionais, desde a mesma distância com respeito ao significado da totalidade e igualmente determinadas pelo êxito, como relações com a música praticadas por quem carece de toda relação" (ADORNO, 2009, p.24).
}

0 ouvinte se comporta portanto de uma maneira projetiva: sua relação se define como um deslocamento de afetos em direção à música, a qual não cumpre mais do que o mero papel de substrato: "Trata-se da submissão do objeto ao esquema mental que dele possuímos, ou seja da apreensão do objeto como projeção de um esquema mental (...)". (SAFATLE, 2007, p.387).

0 critério para a seleção musical tanto por parte dos ouvintes como dos meios difusores passa a ser a eficácia da música em impregnar-se no ânimo do ouvinte e em satisfazer suas necessidades afetivas. Aqui passamos a uma segunda dimensão do diagnóstico adorniano: a função social. Em Weber, um dos sentidos da racionalização musical é o desatrelamento da música a funções sociais - Weber refere-se à função religiosa, que confere à música um caráter prático-finalista - e tal desatrelamento constitui também um dos sentidos já abordados da autonomia da forma. No entanto, à medida que a música passa a ser difundida e consumida não em virtude de suas qualidades objetivas internas mas em função das necessidades afetivas do ouvinte, ela em certo sentido joga por terra sua autonomia e readquire uma função social. Se passarmos da psicologia à sociologia, podemos definir sua função social como uma subordinação da música ao êxito comercial na medida em que o critério da eficácia psicológica não se restringe às escolhas individuais mas determina também os mecanismos de difusão e, portanto, define o lugar social dessa música. Assim, no capitalismo tardio "(...) a possibilidade da autonomização da esfera estética de valor teria sucumbido à colonização da arte pela formamercadoria." (SAFATLE, 2007, p.377)

A música tornada fetiche se submete exclusivamente ao critério do êxito comercial: "A seleção mesma das obras standards se rege por sua 'eficácia', precisamente no sentido das categorias do êxito (...)". (ADORNO, 2009, p.22). Como este mesmo êxito depende diretamente de que a música possa intervir no estado anímico do ouvinte, e como seu estado anímico já não possui relação alguma com a música, o critério ao qual a música fetichizada se submete - não só na disposição do ouvinte à música como também na seleção de repertório da "vida musical" - tampouco tem algo de musical. A mudança de função consiste portanto na substituição de uma relação em que a música era apreciada esteticamente e, deste modo, submetida a critérios de julgamento valorativo em função de suas qualidades objetivas, por uma relação na qual ela supre necessidades afetivas dos seres humanos, por oferecer-se como substrato para o deslocamento de seus afetos. Este é o seu novo lugar social.

A colonização da arte pela forma-mercadoria - que Adorno identifica não apenas na música de massas, produzida diretamente para o mercado, mas também na chamada música séria, isto é, naquela música cuja produção não é ainda afetada diretamente pelo critério de vendabilidade e que reivindica para si um valor estético - não afeta a música exclusivamente no que diz respeito à sua função social. Para além de sua relação direta ou indireta com o mercado e com o êxito comercial, a forma-mercadoria constitui sua estrutura objetiva: a constituição interna da música sofre transformações - e neste caso tratar-se de música "leve" ou música "séria" é indiferente. Aqui passamos à terceira dimensão do diagnóstico adorniano. Vejamos como Adorno define a estrutura interna da música fetichizada:

"Que se consumam 'valores', que estes carreguem em si afetos, sem que suas qualidades específicas sejam alcançadas pela consciência do consumidor, é uma expressão ulterior de seu caráter de mercadoria" (ADORNO, 2009, p.24). 
Adorno pensa aqui o conceito de fetichismo musical a partir de uma referência importante ao conceito de fetichismo da mercadoria em Marx. Como evidencia a citação a Marx², o que Adorno enfatiza é a dinâmica por meio da qual um corpo natural, imediatamente apreensivel pelos sentidos, se separa do processo social de determinação do seu valor, o qual aparece como uma qualidade natural particular desse corpo. 0 trabalho humano - que constitui, juntamente com as características naturais dos materiais com os quais opera, uma das fontes do valor - é tomado como se fosse uma característica natural da mercadoria. Para Marx, o que permite que as mercadorias sejam trocadas é o fato de envolverem uma determinada quantidade de trabalho humano para sua produção, quantidade esta variável para cada mercadoria, mas que possibilita uma relação quantitativa entre elas totalmente independente de suas qualidades específicas. Esse componente abstrato da mercadoria, que envolve uma relação entre os homens por meio do trabalho humano, é tomado como uma característica natural do objeto, e as relações quantitativas entre as diferentes mercadorias são tomadas como relações existentes nas próprias coisas, no próprio corpo da mercadoria, e não entre homens: aquilo que é universal é tomado como particular.

Em Marx o fetichismo da mercadoria consiste portanto em que esta é tomada por um corpo natural, sensivel, no entanto dotado de qualidades sobrenaturais, suprasensiveis. Da mesma forma, em Adorno a música fetichista se define como um objeto sensivel dotado de qualidades supra-sensíveis. Aqueles elementos abstratos e universais que, por estarem sedimentados na consciência auditiva do ouvinte, a tornam imediatamente apreensivel são tomados pelo ouvinte fetichista como propriedades particulares do instante musical, como algo imediatamente disponível. A estrutura da música fetichizada é definida essencialmente a partir desta dinâmica por meio da qual um universal é tomado por particular - dinâmica esta que constitui o quid pro quo [tomar uma coisa por outra] a que Adorno se refere (ADORNO, 2009, p.26). Tendo abstraido todas as qualidades específicas do objeto, o ouvinte fetichista consome na realidade valores de troca lá onde crê que percebe qualidades sensíveis, isto é, percebe elementos musicais universais abstratos onde crê que percebe aquilo que há de mais singular e concreto. Para compreender esta nova essência da música, seria útil observarmos como ela se contrapõe ao que seria, na concepção de Adorno, uma essência da moderna música ocidental não fetichizada, para a qual o filósofo julga inadequada qualquer definição positiva.

No texto Sobre a Relação Atual entre Filosofia e Música, cuja questão principal é justamente a possibilidade de determinação de uma essência da música - compreendida aqui apenas a música moderna ocidental -, Adorno aborda aquilo que considera central a ela: seu caráter racional, ou linguístico, pensado justamente a partir de Max Weber. No entanto, para Adorno a racionalidade da música, ou o seu caráter linguístico, tem uma "essência dupla":
"Por uma parte, implica que a música, através da disposição sobre o material da natureza, se transforma em um sistema mais ou menos rígido, cujos momentos singulares têm um significado independente do sujeito e ao mesmo tempo aberto a ele. Toda música, desde o princípio da época do baixo contínuo até hoje, está unida como um 'idioma', que em boa medida está dado pela tonalidade, e cujo poder continua ainda na negação atual da tonalidade. 0 que designa o termo 'musical' no uso mais simples da linguagem, se refere justamente a esse caráter idiomático, a uma relação para com a música na qual seu material, em virtude de sua objetivização, se converte em segunda natureza do sujeito musical. Mas, por outra parte, também sobrevive, no momento da música semelhante à linguagem, a herança do pré-racional, mágico, mimético: graças à sua linguistização, a música se afirmou como órgão da imitação (...)" (ADORNO, 2000, p.76).

Assim, a música é determinada, por um lado, mediante a abstração de todas as qualidades que venham a constituir a singularidade de uma música determinada. 0 que se obtém por meio desta abstração é aquilo que é comum entre elas: os elementos musicais sedimentados por meio do trabalho de dominação do material sonoro pela forma musical, elementos estes que se abstraíram desta ou daquela música em particular para constituírem um referencial abstrato compartilhado daquilo que é "musical", que estabeleceria os padrões de reconhecimento e legitimidade ante os quais os momentos expressivos e particulares de cada música deveriam se curvar.

Por outro lado, a música não pode ser compreendida sem uma consideração de seus momentos expressivos, nos quais vai além dos elementos convencionais, em direção a algo que tende ao informe e ao "pré-racional": nesses momentos, ela se particulariza e alcança algo que é singular a uma música determinada e a distingue das demais. Para Adorno, a especificidade da linguagem musical, aquilo que Ihe é próprio no interior do pensamento, não pode ser compreendido a não ser a partir dessa "essência dupla". Este é um dos pontos da crítica de Adorno a Weber:

"A [história] da música é, inquestionavelmente, a história de uma racionalização progressiva. (...) Não obstante, a racionalização (...) só constitui um de seus aspectos sociais, assim como a própria racionalidade, a Ilustração; só um momento na história da sociedade de sempre, ainda irracional, 'naturalista'. Dentro da evolução global em que participou da racionalidade progressiva, no entanto, ao mesmo tempo, a música sempre foi também a voz do que no caminho dessa racionalidade se deixava para trás ou do que fora vítima" (ADORNO, 2006, p.14).

A música tornada fetiche perde justamente essa dupla essência, constituindo-se exclusivamente de elementos universais, abstratos. É como se, para Adorno, o conceito weberiano de racionalização do material musical fosse levado a cabo justamente ali onde a música se tornasse um fetiche, se emancipasse de todo vínculo com o particular. 0 que parecia ser uma autonomia do momento parcial em relação à totalidade - como se os elementos de estímulo que, no classicismo, eram ligados entre si por meio da forma unitária, pudessem agora falar por si mesmos - adquire na realidade o sentido contrário. 0 todo é imediatamente apreensível nos momentos individuais como algo já disponível, sem que fosse necessário esforço 
algum para realizar as mediações entre um e outros. 0 universal apresenta-se emancipado de todo vínculo com o particular, de modo que esse elemento ao qual Adorno se refere, que tende ao informe, ao pré-racional, fica ausente.

Isto torna-se claro nos comentários de Adorno sobre - Prelúdio para piano em Dó sustenido menor de Rachmaninoff. Trata-se de um prelúdio constituído por uma mesma cadência repetida inúmeras vezes. Adorno entende o movimento cadencial, dado pelas notas LáSol\#-Dó\# do baixo, como uma referência à progressão por graus melódicos do baixo da passacaglia ${ }^{3}$. No entanto, em Rachmaninoff o único que aparece é o movimento cadencial, cuja função é concluir a frase (Ex.1), mas que o compositor "emancipou por completo de todo conteúdo - de tudo o que sucede musicalmente - e o lançou como mercadoria ao mercado" (ADORNO, 2006, p.291). 0 contracanto melódico, que poderia tornar-se um princípio de estruturação diferente do princípio harmônico da cadência, na ótica de Adorno também se subordina a ela. Em relação a isto, Adorno parece ter em mente o fato de que a terça ascendente e a segunda descendente $e_{\text {, }}$ logo adiante, o giro napolitano (c.2-3) - terça diminuta descendente e segunda menor ascendente - não apenas permanecem circunscritos ao movimento cadencial determinado pelos graus melódicos do baixo como são repetidos quase sempre idênticos. A partir do quarto compasso, quando uma progressão parece levar a música para fora da tonalidade original - o que na realidade não ocorre - as repetições melódicas se apresentam variadas, mas tais variações são contingentes: são casos isolados que não constituem nenhum princípio dinâmico que possa se opor à rigidez da cadência. Trata-se apenas de transposições, cuja referência ao modelo é claramente percebida e que ocorrem duas vezes antes do retorno do motivo original, de modo que não se pode falar de um

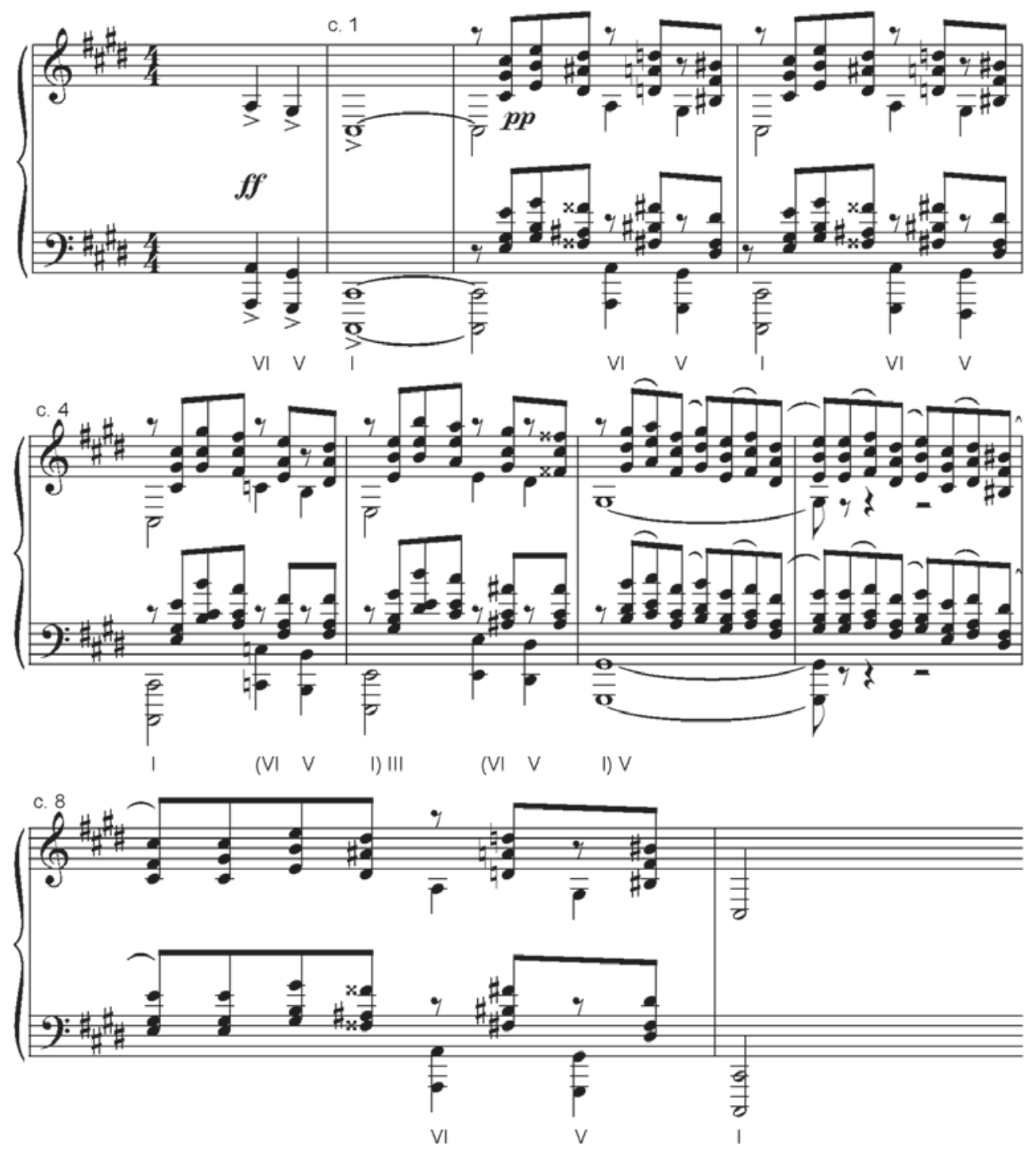

Ex.1 - Prelúdio para piano Op.3 №2 (c.1-9) de Rachmaninoff. 
processo de transformações, quer seja por variação, quer seja por desenvolvimento. 0 mesmo pode-se dizer da parte contrastante - ou parte B - do prelúdio, cuja "soltura virtuosística" não compensa, para Adorno, o fato de ser mera repetição do contracanto, impotente como elemento estrutural que pudesse opor resistência à soberania do movimento cadencial. 0 motivo de notas descendentes do segundo compasso até a cabeça do terceiro aparece com as mesmas notas nos compassos 14 e 15 e o motivo constituido por uma terça ascendente e uma segunda descendente aparece de diversas formas no compasso 16 - original, inversão, retrogradação e retrogradação da inversão -, tudo sobre uma harmonia estacionada na tríade de Dó sustenido menor, seguida pelos graus melódicos VIV-I no baixo mais uma vez, no compasso 17, no entanto com um II entre o VI e o V (Ex.2). Em seguida esses mesmos motivos se apresentam transpostos para outras alturas sem alteração rítmica, sobre um movimento harmônico maior porém não suficiente para abalar a sensação do dó sustenido menor como tônica. As características mais gerais da parte B são a alteração do padrão de subdivisão binária para o de subdivisão ternária, o predomínio da tônica e dos graus cadenciais e o descenso por graus conjuntos, a partir do compasso 35 (Ex.3), em um prolongamento da tônica que vai até o início da cadência, isto é, o retorno da parte A. Tais características sugerem uma típica afirmação da tônica que costuma aparecer nas grandes formas ${ }^{4}$, nos momentos de conclusão, antecedendo e reforçando a cadência final. No entanto, esta mesma cadência era 0 único elemento que constituía a primeira parte, de modo que a peça inteira soa como uma conclusão sem que nela haja algo para ser concluído.
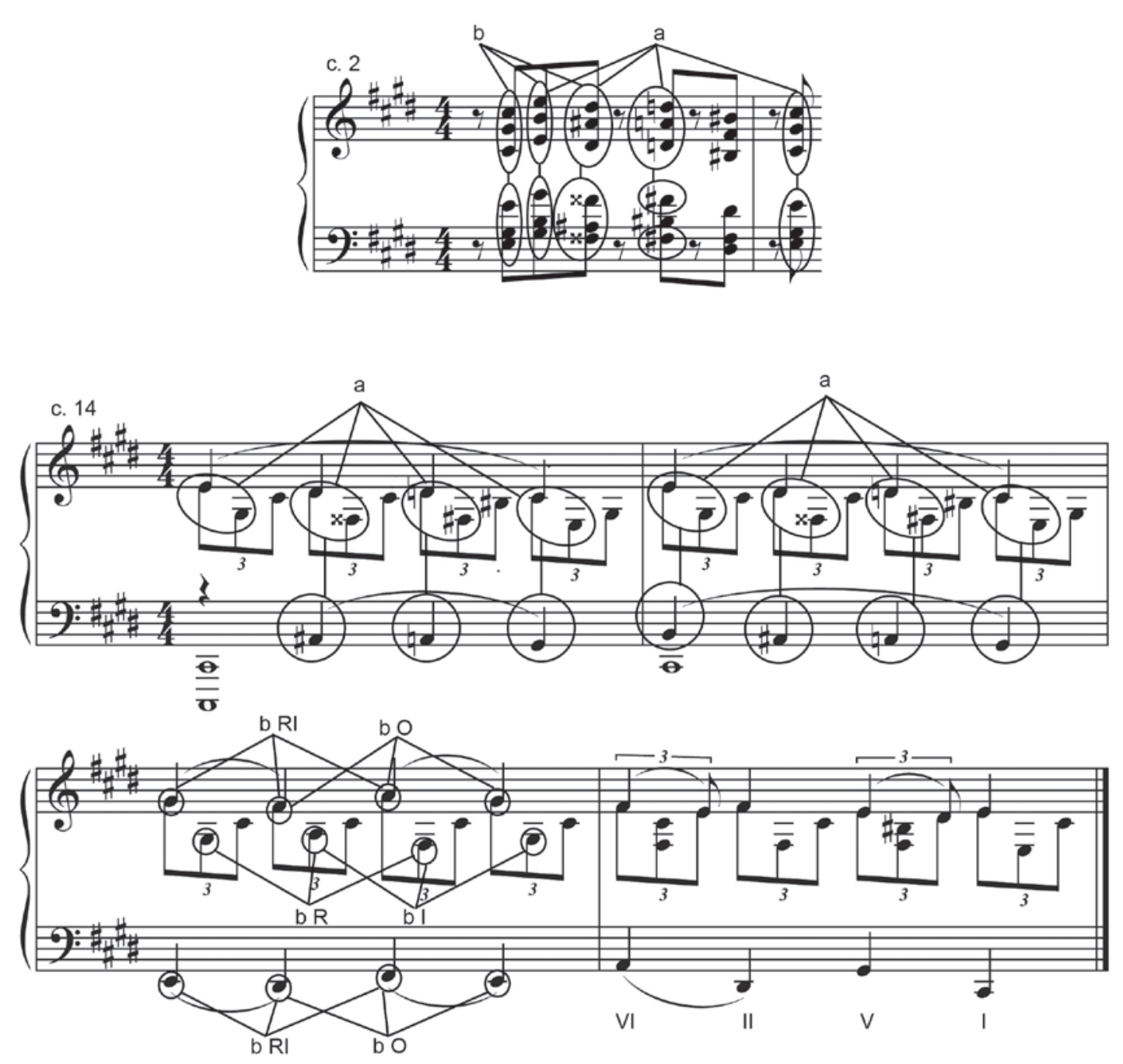

O: original; I: inversão; R: retrogradação; RI: retrogradação da inversão

Ex.2 - Prelúdio para piano 0p.3 №2 (c.14-17) de Rachmaninoff: notas iniciais do contracanto sem o baixo (c.2) e início da parte B. 

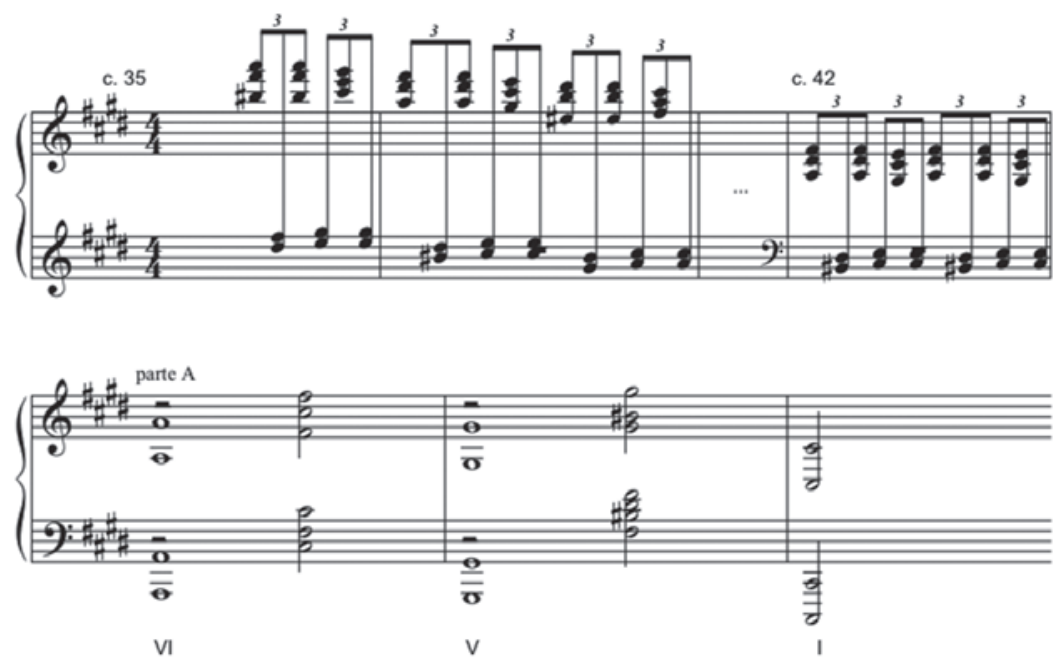

Ex.3 - Prelúdio para piano Op.3 №2 (c.35-45) de Rachmaninoff.

A cadência constituída pelos graus melódicos VI-V-I elemento idiomático comum na música romântica, que aparecia para afirmar uma tonalidade na conclusão de uma frase ou seção - se faz passar por um elemento de inspiração, singular a esta música, como uma propriedade do compositor injetada na música. A fácil assimilação dessa cadência - garantida pelo seu caráter universal enquanto cadência - produz a impressão de existirem qualidades sensiveis ocultas, isto é, propriedades particulares do instante musical enquanto tal, e que estariam para além de suas determinações sensiveis, mas que são percebidas pelo ouvinte como uma particularidade. 0 processo social descrito por Weber de racionalização harmônica do material musical - por meio do qual os traços idiomáticos, dentre os quais a cadência, são sedimentados na consciência musical e tornam-se assim assimiláveis - encarna-se no corpo sensivel da música e tudo se passa como se tais traços idiomáticos convencionais presentes nela fossem em si mesmos musicais e inspirados. A estrutura harmônica abstrata, uma vez emancipada de tudo o que pode haver de particular na música e de tudo o que não é cadência conclusiva, é vista ela própria como uma qualidade particular. Tanto aqui como diagnóstico marxiano sobre o fetichismo da mercadoria, ao qual Adorno faz referência, toma-se uma coisa pela outra: toma-se o universal como se fosse um particular. A estrutura da música fetichizada reproduz esse quid pro quo: o todo migrou para as partes e se autonomizou completamente de qualquer particularidade, ou, para mantermos os termos weberianos, de qualquer "irracionalidade": tornou-se uma totalidade vazia, abstrata, que não obstante aparenta ser o que há de mais pleno, concreto e disponível.

\section{4 - Expressão e convenção}

A reflexão de Adorno sobre a música nova da Segunda Escola de Viena é inseparável desse diagnóstico de que toda música que se insere mais ou menos comodamente nos moldes tradicionais já não pode sobreviver enquanto música. Se os momentos parciais soam em si mesmos familiares aos ouvidos, isto é suficiente para que ante a escuta o todo se desagregue e a música se transforme em fetiche. Ou melhor: para que a parte se transforme ela mesma em uma totalidade autônoma, imediatamente presente. Vimos que para Adorno as melodias "profanas", os "estímulos aos sentidos", os elementos de "superficialidade", presentes em Haydn soavam familiares aos ouvidos da época, e que no entanto graças ao princípio da autonomia da forma, a música realizava uma superação desses momentos efêmeros. Aqueles elementos completamente familiares passavam a produzir estranhamento ao serem desenvolvidos e ligados no interior uma forma complexa, o que evidencia o poder de diferenciação e ressignificação que o princípio unitário da forma autônoma exercia sobre materiais que em um primeiro momento soavam familiares. Esse aspecto dinâmico na relação entre as partes e o todo é perdido na música fetichizada, na qual em última instância não há partes mas apenas um todo, um princípio abstrato, um clichê, um emprego de meios musicais já sedimentados e portanto reconheciveis isoladamente - como por exemplo o movimento cadencial - que, ao se apresentar como algo imediatamente disponivel, para além de qualquer mediação temporal, de qualquer relação com elementos musicais mais particularizados, menos imediatos e reconheciveis, é tomado como se fosse um particular.

Tal dinâmica entre o reconhecível, o imediato, de um lado, e o pouco reconhecível, o mediato, de difícil apreensão, de outro, é uma importante questão no que toca ao conceito de expressão musical, de modo que, por meio deste conceito, poderemos apresentar o expressionismo musical como um movimento intrinsecamente marcado pelo problema do fetichismo musical. Em um texto em que pretende desfazer alguns mal-entendidos a respeito da estética do sentimento, Dahlhaus aborda a questão da expressão apontando uma transformação pela qual este conceito passou por volta do final do século XVIII e início do XIX. 
Até essa data, a expressão era tida como uma propriedade objetiva da música enquanto tal, sem que as emoções ou afetos expressados precisassem estar presentes nos ouvintes, no intérprete ou no compositor. "Os movimentos dos sons desencadeiam por simpatia os da alma (...) e estão sujeitos às mesmas leis que os impulsos psíquicos". (DAHLHAUS 2003, p.33). Portanto, a rigor, os afetos não eram expressados mas sim desencadeados e provocados em virtude de uma afinidade entre os sons e a alma. Em contraposição a isto, o novo conceito de expressão, isto é, o conceito romântico, não afirmava mais uma "simpatia" entre os sons e os estados psíquicos, pois os afetos não eram mais desencadeados por simpatia: os sons eram na realidade "sinais naturais" dos sentimentos. 0 que se obtém nesta transformação é que, ao invés de representar sentimentos exteriores a ela, a música continha os sentimentos, isto porque o compositor registrava nela seus próprios sentimentos subjetivos. De acordo com o conceito romântico de expressão, diz Dahlhaus, a expressão não se esgota nos elementos musicais objetivos, cuja afinidade com os estados psíquicos os tornava "expressivos", mas abriria espaço para o compositor "forçar sua egoidade à música" (DAHLHAUS, 2003, p.35). A expressão ganhava assim uma dimensão subjetiva, que se exprime na ideia de um sujeito-compositor que visa penetrar na obra ao afastar-se dos meios musicais catalogados e objetivados rumo à singularidade.

Essa distinção que Dahlhaus apresenta, a partir de uma análise de fontes primárias, entre a expressão até o fim do século XVIII e a expressão romântica não parece ser aceita por Adorno, que aproxima ambas sob o termo de "música expressiva ocidental":

"A música 'expressiva' ocidental, desde princípios do século XVII, assumiu a expressão que o compositor atribuia a suas obras (...) sem que as emoções expressadas pretendessem estar imediatamente presentes e serem reais à obra. A música dramática, verdadeira música ficta, ofereceu, de Monteverdi a Verdi, um modo de expressão estilizado e ao mesmo tempo mediato, isto é, a aparência da paixão". (ADORNO, 2004, p.39).

Não apenas Adorno identifica na música anterior ao século XIX essa inclinação à expressão que o próprio compositor "atribuía a suas obras" e, consequentemente, essa relação de oposição entre o sujeito-compositor e objetividade musical à qual Dahlhaus atribui importância apenas a partir do fim do século XVIII e início do XIX. Além disso, a expressão romântica trairia, para Adorno, seu próprio conceito, na medida em que a expressão subjetiva só se realiza musicalmente por meio da "aparência da paixão". 0 que se obtém é menos a expressão singular de conteúdos subjetivos e mais a estilização destes conteúdos por meio de temas, leitmotivs, acordes etc. que se ofereceriam como um meio de acesso aos conteúdos mentais expressados neles, sem que seja possível estabelecer qualquer continuidade entre estes e aqueles. 0 problema da relação entre os conteúdos subjetivos e os meios musicais objetivos - ainda que "fictos" - permanecia não resolvido, para além da determinação dos segundos como "sinais naturais" dos primeiros. Essa contradição entre expressão subjetiva e meios musicais objetivos sugere que ambos são conceitos excludentes, que cada um deles predominaria em detrimento do outro. Assim, a realização da expressão se conseguiria mediante a liberação progressiva em relação a esses meios, conforme mostra Adorno:

"O que poderia realizar-se nestas condições [de dissolução da obra autônoma] parece ilimitado. Todos os princípios seletivos e restritivos da tonalidade caíram. A música tradicional devia encontrar-se nos limites de um número extremadamente limitado de combinações sonoras, especialmente no sentido vertical. Devia defender-se continuamente contra o especifico, mediante constelações do universal, que, paradoxalmente, deviam apresentá-lo como idêntico ao irrepetivel" (ADORNO, 2004, p.48).

Se a busca da particularização resulta no seu oposto - na convenção, na estilização da expressão por meio figuras reconhecíveis - isto era atribuido ao fato de que ainda não se havia conseguido derrubar todas as amarras que a convenção impunha ao ato criador. Contra tais amarras, o sujeito-compositor deveria imprimir-se na obra por meio da recusa a todo elemento convencional pré-estabelecido. Entretanto, Adorno não compreende a relação entre expressão e convenção nesses termos, como se a realização da expressão dependesse de que todos os meios "seletivos" e "restritivos" da convenção fossem pura e simplesmente abandonados, de modo que o sujeito-compositor se afirmasse contra a objetividade através da simples aniquilação dos elementos objetivos.

\section{5 - Erwartung: Expressão como negação da convenção}

Mesmo assim, é interessante determo-nos na maneira romântica de compreender relação entre expressão e convenção pois o conceito expressionista de expressão, sobretudo da maneira como ele se apresenta em Erwartung, deriva da expressão romântica. É por isso que Adorno situa o momento de ruptura de Schoenberg expressionista não como ruptura com o "exagero" da expressão romântica, mas como radicalização justamente desse "exagero":

\footnotetext{
"Entre os argumentos que quiseram deslocar o incômodo Schoenberg para o passado do romantismo e do individualismo (...), o mais difundido é o que o considera como 'músico do expressivo', e considera sua música como 'exagero' do princípio de expressão, tornado agora caduco. (...) É importante, em compensação, o expressivo de Schoenberg desde o momento de ruptura que remonta pelo menos às Obras para piano, opus 11, e aos Lieder sobre textos de George, onde se manifesta qualitativamente diferente do romântico, graças a esse 'exagero' do princípio da expressão" [grifo meu] (ADORNO, 2004, p.39).
}

A transformação introduzida pela música de Schoenberg só pode ser compreendida a partir daquilo que ela conserva da música romântica: o exagero da expressão. A ideia romântica de que a expressão só poderia chegar no seu mais alto grau de realização ali onde todos os elementos convencionais caíssem por terra; de que o sujeito-compositor se reconciliaria com a música ali onde todas as fórmulas fossem abandonadas, seria levada a cabo justamente por Erwartung, que foi vista, "em termos de história da composição", "como a realização da ideia de uma música que é atemática e não definível através de 
categorias formais" (DAHLHAUS, 1990, p.149). No entanto, Adorno identifica nessa radicalização da expressão uma mudança qualitativa em relação à expressão romântica:

\begin{abstract}
"Nele [em Schoenberg], o único momento propriamente subversivo é a mudança de função da expressão musical. Já não se trata de paixões simuladas, mas antes de movimentos corporais do inconsciente, de shocks, de traumas, que ficam registrados no meio da música. Atacam os tabus da forma já que estes submetem tais movimentos à sua censura; racionaliza-os e os transpõe em imagens" (ADORNO, 2004, p.40)
\end{abstract}

Assim, a emancipação em relação aos elementos da tradição teria sido levada a cabo pelo procedimento documental, de registro de movimentos corporais, com o qual os elementos formais que na música tradicional garantiam a continuidade são aqui postos em xeque. $E_{1}$ ao mesmo tempo, tal procedimento define o novo caráter da expressão não mais como "paixões simuladas", mas como registro de shocks. No entanto, o resultado disso não é a simples negação da forma e aqui começa a reviravolta:

\footnotetext{
"O registro sismográfico de shocks traumáticos converte-se ao mesmo tempo na lei técnica da forma musical. Esta lei proíbe toda continuidade e desenvolvimento. A linguagem musical se polariza em seus extremos: atitudes de shocks e análogos estremecimentos do corpo, por um lado; e por outro expressa, vítreo, aquilo que a angústia torna rígido" (ADORN0, 2004, p.42).
}

0 procedimento documental, de registro, define a forma musical do Schoenberg expressionista para Adorno - sobretudo no caso de Erwartung. Os movimentos orgânicos imediatos, não censurados nem mediatizados por uma codificação dos sentimentos, aquilo que brota do sofrimento e da angústia enquanto tais ficam registrados na música. 0 procedimento de registro da paixão como gesto orgânico não racionalizado se contrapõe assim ao de simulação da paixão por meio da associação de determinados temas, harmonias e passagens a determinados sentimentos, pelo qual os sentimentos adquirem em tais temas, harmonias ou passagens um caráter racional, objetivado e portanto mediatizado. Esta definição que Adorno faz da forma em Erwartung é tomada como ponto de partida na análise que Dahlhaus realiza do monodrama, cujo objetivo é "tentar fazer compreensível em termos de técnica composicional aquele senso formal que Adorno definiu exclusivamente em termos negativos, como falta de 'continuidade e desenvolvimento'" (DAHLHAUS, 1990, p.150). Dahlhaus não nega a impossibilidade de se fazer uma análise temática do monodrama, no entanto sua análise se volta aos elementos motívicos.

Dahlhaus compreende Erwartung como uma peça dividida em seções, cada qual constituída por um motivo predominante. Sua análise se detém em uma dessas seções, na qual identifica um motivo que pode ser facilmente apreendido como o principal: tratase do Mi-Ré\#-Lá em que a voz canta "Wie kannst du tot sein", nos compassos 245 e 246 . No entanto, Dahlhaus afirma em seguida que o verdadeiro motivo que estrutura a passagem é constituido pelas notas
Réb-Dó-Lá, tocadas no compasso 246 pelos contrabaixos - conforme Dahlhaus indica, provavelmente por ser neles mais audivel, pois aparece no registro agudo do instrumento - mas também pela harpa, pelos fagotes, pelo contra-fagote e pelo clarinete baixo (Ex.4). Trata-se de um motivo, ao contrário do anterior, de difícil apreensão. Não obstante, Dahlhaus o considera o motivo principal fundamentalmente por duas razões, ambas relacionadas à estruturação da música. Por um lado, ele torna possivel resolver um dos problemas principais com que uma análise de Erwartung se depara:

\begin{abstract}
"O problema composicional central de uma obra cuja 'lei estrutural', como Adorno coloca, proibe 'continuidade e desenvolvimento' é estabelecer razões para que as seções se sucedam na ordem em que elas se sucedem" (DAHLHAUS, 1990, p.152).
\end{abstract}

No compasso 242, as "figuras explosivas" da orquestra entram em contraste com a atmosfera tranquila e introspectiva da seção que termina no compasso anterior. Diante do problema apresentado na citação acima, qual seja, o de estabelecer o nexo entre seções descontínuas, Dahlhaus aponta, em primeiro lugar, uma intercalagem entre uma seção e outra dada pelo deslocamento do contraste textual em relação ao musical, o que é de pouco interesse para nós. Em segundo lugar, e é isto que mais nos interessa, o motivo Réb-Dó-Lá mencionado adquire uma função de mediação desse contraste que ocorre musicalmente na passagem do compasso 241 para o 242 (Ex.4). Os elementos que constituem o contraste propriamente dito são a dinâmica (passa-se de um pp para um fff), o volume sonoro (dado pelo aparecimento de um quase tutti orquestral no compasso 242, em oposição à leveza do compasso anterior) e o timbre (no lugar do oboé como voz principal [Hauptstimme] no compasso 241, têm-se agora as cordas e, como uma voz secundária que, embora não seja indicada como tal, é bastante audivel, os metais). Dahlhaus mostra haver uma articulação conseguida graças ao aparecimento do motivo Réb-Dó-Lá tanto no oboé - mas também na voz e no fagote -, no compasso 241 , como nos metais, no compasso seguinte (nessa voz que identificamos como secundária), em sua forma original, embora transposto em ambos casos. Assim, "o contraste não permanece sem que sejam feitas as mediações".

Uma das razões que leva Dahlhaus considerar o motivo Réb-Dó-Lá como o principal do trecho que toma para analisar é, pois, sua função estrutural de mediação do contraste mencionado. A outra razão, que possivelmente não exclui a primeira, é a função como um dos "elementos estruturais que formam a base da expressividade" (DAHLHAUS, 1990, p.150) em Erwartung. Dahlhaus não faz uma simples oposição entre a expressividade e os elementos objetivos - como a polifonia e o contraponto - mas compreende ambos como co-dependentes: 0 contraponto, a relação contrapontística entre as várias vozes, dada pela permanência de alguns elementos e 
b
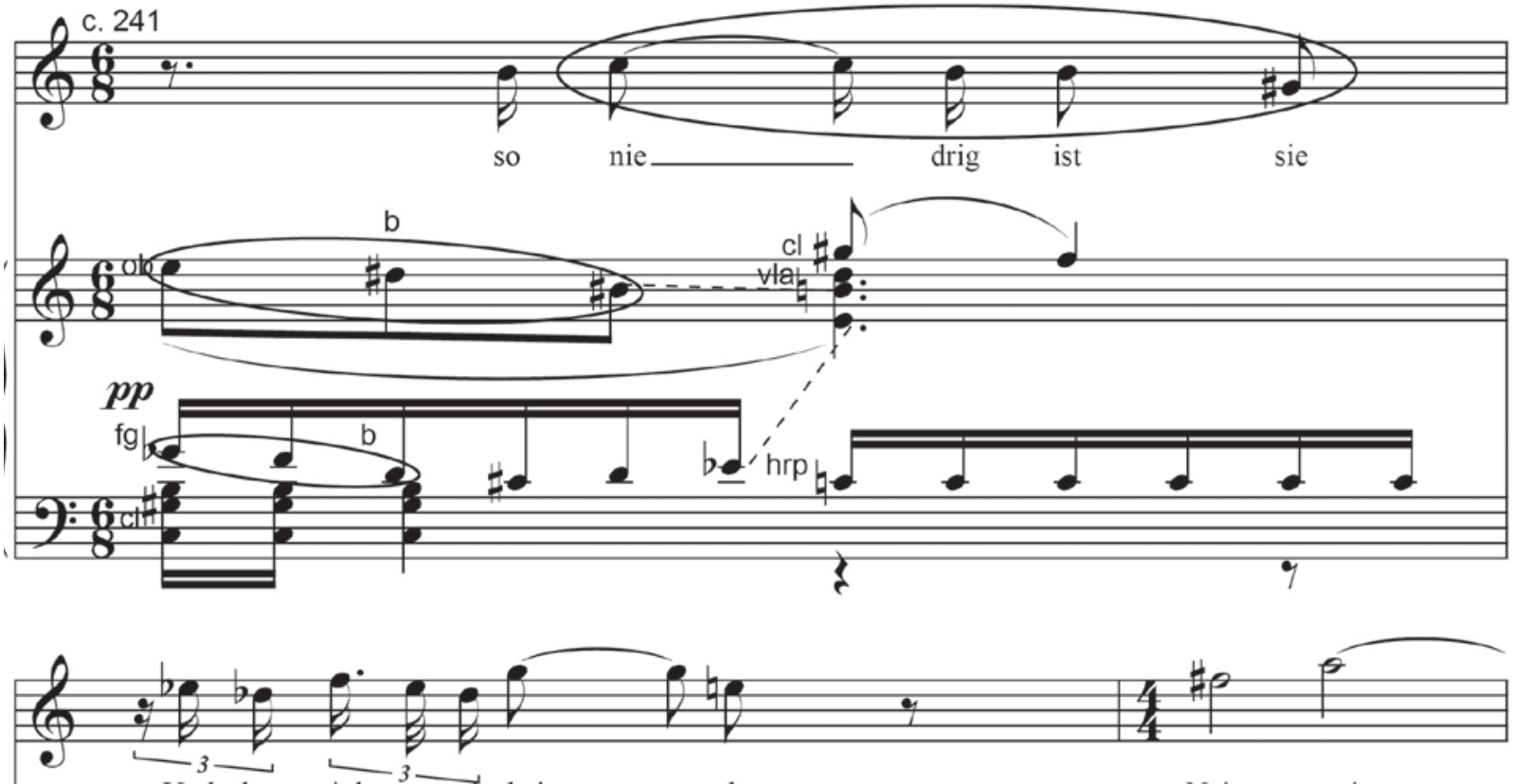

Und dann wink - ten wir bei___ de

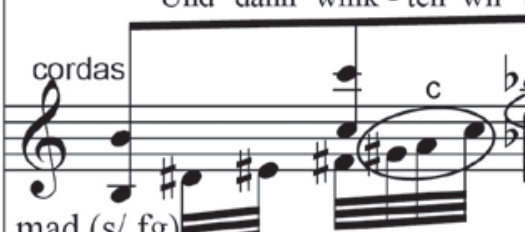

$\operatorname{mad}(\mathrm{s} / \mathrm{fg}) \rightleftharpoons$

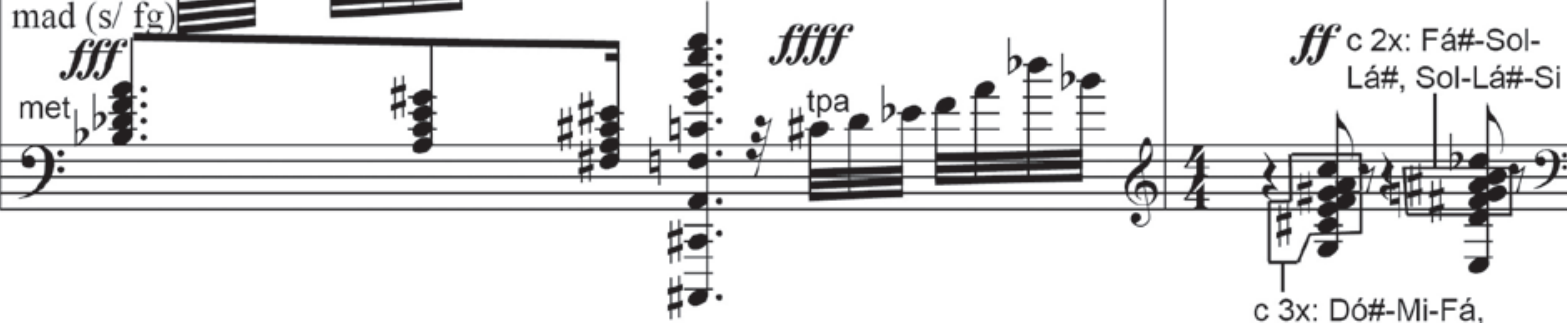

Mi-Fá-Sol\#, Sol\#-Lá-Dó

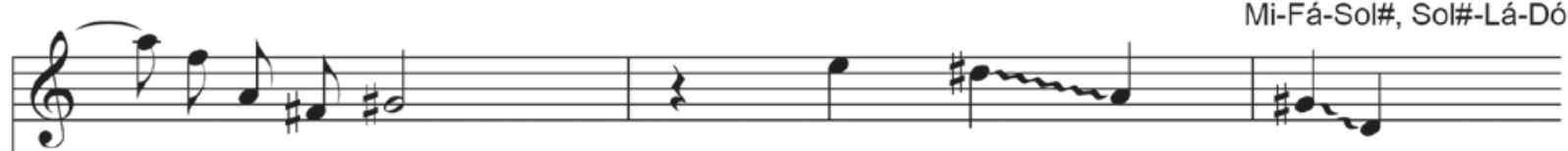

es ist nicht wahr

Wie kannst du

tot sein?
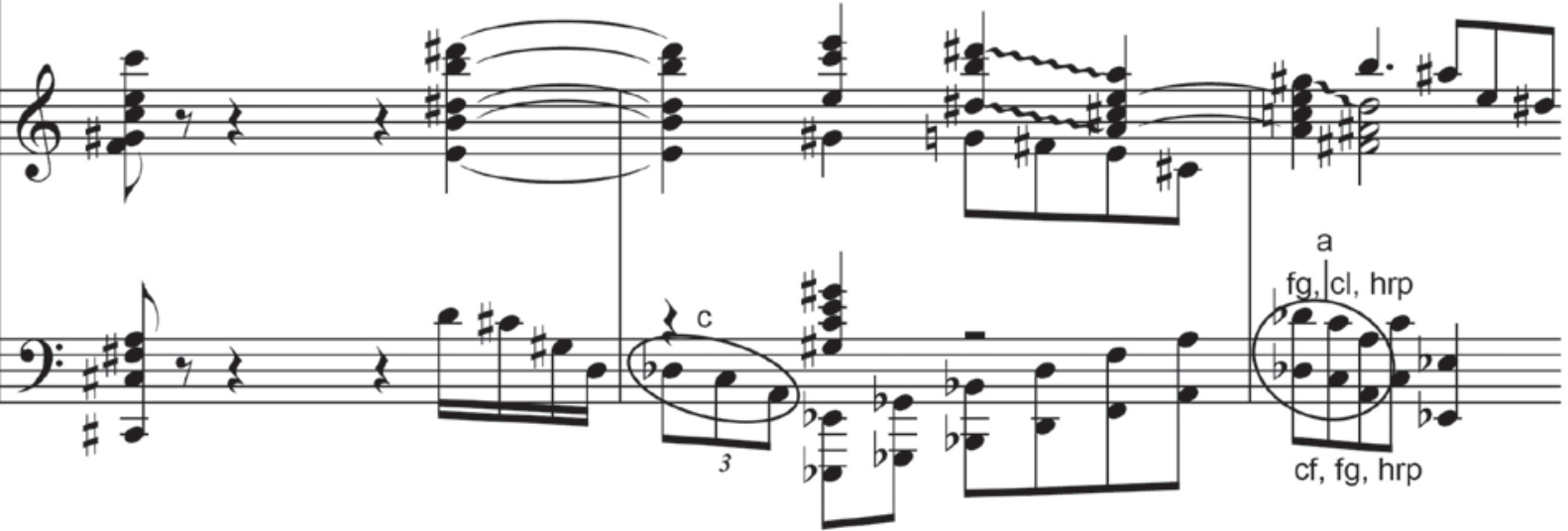

a: motivo principal da seção segundo Dahlhaus; b: aparições do motivo com a função de articulação de contraste; c: outras aparições literais, melódicas e harmônicas, do motivo

Ex.4 - Erwartung (c.241-246) de Schoenberg: trecho transcrito para piano e voz literalmente, ou seja, sem adaptações nem omissões de notas ou dobramentos. 
pela variação de outros, é justamente um recurso da expressividade pois

\begin{abstract}
"quanto mais 'eloquente' é uma voz contrapontística - e quanto mais significante é o que ela tem a dizer - tanto mais enfaticamente ela se imprime na consciência do ouvinte inteligente como parte do discurso contrapontístico. (...) $E_{1}$ inversamente, a expressividade de uma voz contrapontística não é diminuída ao ser combinada simultaneamente com outras vozes 'eloquentes'; em vez disso - por meio de contraste, ao ser posta em relevo ou em algum processo de complementação - ela é realçada" (DAHLHAUS, 1990, p.151).
\end{abstract}

A base do discurso contrapontístico de Erwartung não é, para Dahlhaus, a igualdade de vozes que caracteriza a textura da fuga, mas a hierarquia entre parte vocal, voz principal [Hauptstimme] voz secundária, [Nebenstimme] e acompanhamento. Nesta hierarquia, os planos mais importantes apresentam caracteres mais claros e os planos de fundo, caracteres cuja apreensão é mais difícil. A expressividade se constitui, assim, conforme Dahlhaus afirma na citação acima, na possibilidade de relacionar aquilo que as vozes apresentam, desde o que salta aos ouvidos como mais claro e compreensível até os elementos mais escondidos, nos quais a música explode nos momentos mais expressivos.

A análise que Dahlhaus realiza de Erwartung mostra que o princípio expressivo não deve ser compreendido, no monodrama, como um princípio cuja realização depende de que caiam por terra todos os elementos convencionais. Os momentos mais expressivos, isto é, em que os "shocks traumáticos" são registrados, apresentam em si uma unidade estrutural latente garantida pelo motivo Ré-Dó-Lá, o qual aparece em diversas vozes no trecho analisado por Dahlhaus, algumas vezes mais audiveis, outras menos; em alguns casos melodicamente, em outros harmonicamente, isto é, as três notas simultaneamente (Ex.4). Isto torna possível que o gesto orgânico, pré-racional registrado da mulher que não se conforma com a morte do homem amado seja objetivado em elementos de linguagem musical, por meio dos quais a música "expressa, vítreo, aquilo que a angústia torna rígido" (ADORNO, 2004, p.42).

É importante ressaltar, entretanto, que aqui o princípio expressivo coloca os meios musicais, isto é, os elementos de linguagem musical que garantem a inteligibilidade do discurso, a serviço do gesto expressivo. Os elementos estruturantes não são iluminados como figuras de primeiro plano, imediatamente apreensíveis, como ocorre, por exemplo, em relação aos temas de uma forma sonata, ao sujeito de uma fuga, aos leitmotifs de uma ópera etc. mas permanecem num nível subterrâneo, inapreensivel a não ser para aquele ouvinte que "não se satisfaz em meramente registrar o fato de que coisas diferentes foram sobrepostas" (DAHLHAUS, 1990, p.151), mas que busca compreender a relação entre elas. Dahlhaus afirma em uma passagem que, no pensamento musical de Schoenberg, os meios linguísticos herdados da tradição são tomados não como fins em si mesmos mas como meios para expressar a "ideia musical":
"(...) com o fim de entender o que Schoenberg compreendia como uma ideia musical devemos lembrar que ele (...) tomava a tonalidade, ou o significado das notas, simplesmente como meios de apresentação e não como a substância das ideias musicais. Para Schoenberg, que insistiu enfaticamente no principio da expressão, o elemento primordial, essencial em uma ideia era seu conteúdo expressivo ou contorno gestual; as funções tonais e conexões eram recursos definidores secundários - os meios para uma formulação compreensível da ideia, não o núcleo da concepção original" (DAHLHAUS, 1990, p.154).

No que diz respeito à expressão, a posição de Adorno - ou pelo menos do Adorno da Filosofia da Nova Música - é mais severa do que a de Dahlhaus: Adorno não parece haverse convencido de que a expressão tenha, em Erwartung, de fato realizado o desafio que a música romântica não conseguira realizar, isto é, superado o congelamento da expressão em determinados meios musicais, e superado a essência romântica da expressão como "constelações do universal, que, paradoxalmente, deviam apresentálo como idêntico ao irrepetível" (ADORNO, 2004, p.48). Com a liquidação de qualquer elemento temático ou motívico no plano de frente, que possa ser acompanhado por uma escuta consciente, isto é, devido ao caráter atemático da obra, tudo o que é negado na estrutura manifesta reaparece na estrutura latente, isto é, nos elementos estruturais não perceptíveis enquanto tais, mas que garantem a unidade do todo. Deste modo, 0 pólo oposto da insubordinação às categorias formais e da liberação da convenção - consequência do procedimento de registro - é, como afirma Adorno, a rigidez motívica que compensa essa ausência de estruturas apreensiveis pela consciência e, deste modo, garante a inteligibilidade e a consistência da obra. No entanto, quando tudo muda, nada pode mudar. Se no nivel das estruturas conscientes não há nada que permanece estável para que o ouvinte possa acompanhar, no nível das estruturas latentes é necessário que nada mude. Essa unidade estrutural de que dependem os momentos mais expressivos, dada por uma rigidez motívica na base da expressividade, é o que parece levar Adorno a afirmar que, com a radicalização do princípio expressivo, expressão e convenção se tocam, com o qual a música torna-se inexpressiva:

\footnotetext{
"A música expressionista havia tomado com tanta exatidão princípio da expressão da música romântica tradicional que ele assumiu o caráter de documento. Mas ao mesmo tempo o inverteu. A música como documento da expressão já não é 'expressiva'. Sobre ela já não pende em vaga distância o que ao estar expressado lhe confere o reflexo do infinito" (ADORNO, 2004, p.47).
}

\section{6 - Conclusão}

Se, por um lado, em uma recusa a todo esquema formal pré-estabelecido de tratamento do material e em nome da expressão pura, imediata, a música adquire a função documental de registrar gestos orgânicos, por outro lado, esses mesmos gestos só se tornam musicalmente consistentes devido a uma extrema rigidez motívica, e portanto estrutural. 0 motivo Réb-Dó-Lá permanece como um elemento fixo que garante a inteligibilidade e consequentemente a expressividade. Isto afeta o que Adorno chama, em um de seus textos, de espaço musical: 
"A quem escuta sem preconceitos as primeiras obras da atonalidade livre (...) se impõe, se é que se pode descrever assim, o sentimento de falta de espaço, de bidimensionalidade. Entre os shocks que esta música lança, um dos essenciais é aquele em que a música nega ao ouvinte o ser incluído, o ser abraçado espacialmente". (ADORNO, 2000, p.81)

A essa música carente de espaço, Adorno contrapõe, entre outras, as obras tardias de Schoenberg, nas quais identifica uma reflexão subjetiva sobre os materiais, o que garante essa espacialidade. Uma das maneiras de produzir essa espacialidade é por meio de temas e motivos que se repetem e, nessas repetições, se transformam e se distanciam cada vez mais dos elementos iniciais, permanecendo, entretanto, a eles ligado pelos elementos mais abstratos. As repetições são, portanto, apreensíveis conscientemente e são elas que, como um solo de identidade, tornam possivel que os materiais iniciais se transformem e assim se renovem. Esta ideia se aproxima do conceito schoenberguiano de variação em desenvolvimento, que Dahlhaus expõe no ensaio What is "developing variation" (DAHLHAUS, 1990). Por meio dessa reflexão subjetiva sobre os temas e motivos objetivos poder-se-ía vislumbrar uma superação do caráter objetivo dos elementos musicais e uma reconciliação do sujeito com a música, não pela negação das estruturas musicais conscientes, mas por meio do trabalho subjetivo sobre elas. É justamente esta transformação e renovação dos materiais que 0 procedimento documental de Erwartung impossibilita ao proibir repetições temáticas ou motívicas apreensiveis conscientemente. Isto torna possivel compreender o que Adorno tem em mente ao afirmar que "Na relação documental com seu objeto, ela mesma [a música] se torna 'objetiva'" (ADORNO, 2004, p.47). Assim, para Adorno, ao levar às últimas consequências o ideal romântico de expressão subjetiva, a música destrói o próprio sujeito. Ao tomar o sujeito como algo pleno de conteúdo, singular, e ao tentar fixar este conteúdo por meio do procedimento documental, o expressionismo cai em uma armadilha da dialética, da qual seu valor estético ou, para dizer como Adorno, seu valor cognitivo, é inseparável: "A revirada produz-se necessariamente. Deriva precisamente do fato de que o conteúdo do expressionismo, o sujeito absoluto não é absoluto. Em seu isolamento aparece a sociedade". (ADORNO, 2004, p.46).

Lidos a partir da questão do fetichismo seria possível então dizer que, apesar das incomensuráveis diferenças em todos os aspectos, Erwartung e o Prelúdio em Dó sustenido menor de Rachmaninoff mencionado acima se tocam em um ponto: na impossibilidade da reconciliação entre subjetividade e objetividade devido à totalidade da forma e sua violência sobre o sujeito. Havíamos chegado a uma formulação segundo a qual a estrutura da música fetichista é marcada pelo emprego de elementos universais, de inteligibilidade imediata, dispostos como se fossem elementos particulares. Assim, no prelúdio de Rachmaninoff, a cadência é utilizada não como um recurso conclusivo, uma pontuação da forma, mas como o material mesmo de que a música dispõe, como algo em si mesmo pleno de sentido. Ao apontar para o particular puro e simples, a música atinge o universal puro e simples. Adorno encontra algo semelhante a esse quid pro quo em Erwartung, a qual visaria um registro documental do sujeito isolado, não mediatizado pelos elementos objetivos da convenção e é em nome disto que toma a decisão diametralmente oposta da de Rachmaninoff e recusa todos os elementos de inteligibilidade imediata - e não obstante se congela no pólo oposto, no objetivismo, isto é, em não poder ser diferente daquilo que é. No entanto, enquanto o prelúdio de Rachmaninoff oferece um asilo seguro ao sujeito, o qual se sente, como diz Berg, "romanticamente confortável como em uma boa poltrona" (ADORNO, 2002, p.622), em Erwartung o isolamento do sujeito destrói este mesmo sujeito, cuja essência aprece estritamente objetiva, como algo rígido e impermeável ao tratamento subjetivo. Erwartung pode ser considerada, entre outras coisas, como a última realização musical da ideia de uma expressão buscada pela recusa dos meios convencionais de inteligibilidade e, com isto, pela recusa total dos materiais fetichizados: da ideia de expressão e convenção como opostos excludentes. E nessa recusa total de materiais fetichizados, eis que surge o risco de outra forma de fetichismo. 


\section{Referências}

ADORNO, Theodor. Sobre la música. Ediciónes Paidós, 2000.

. Essays on Music. University of California Press, 2002.

. Filosofia da nova música. São Paulo: Perspectiva, 2004.

. Obra completa v. 16: Escritos Musicales I-III. Madrid: Akal, 2006.

. Obra completa v. 14: Disonancias / Introducción a la sociología de la música. Madrid: Akal, 2009.

DAHLHAUS, Carl. Schoenberg and the New Music. Cambridge University Press, 1990.

Estética Musical. Lisboa: Edições 70, 2003.

NATTIEZ, Jean-Jacques. Tonal / Atonal. In: Enciclopédia Einaudi, v. 3. Lisboa: Imprensa Nacional - Casa da Moeda, 1984.

SAFATLE, Vladimir. Fetichismo e mimesis na filosofia da música adorniana. In: Revista Discurso № 37. São Paulo: Alameda, 2007.

SCHOENBERG, Arnold. Fundamentos da composição musical. São Paulo: Edusp, 1996.

WAIZBORT, Introdução. In: WEBBER, Max. Fundamentos racionais e sociológicos da música. São Paulo: Edusp, 1995.

WEBER, Max. Fundamentos racionais e sociológicos da música. São Paulo: Edusp, 1995.

\section{Leitura Recomendada}

ALMEIDA, Jorge de. Crítica dialética em Theodor Adorno: música e verdade nos anos vinte. Cotia: Ateliê Editorial, 2007.

MACHADO, Carlos Eduardo Jordão. O Debate sobre o expressionismo: um capitulo da história da modernidade estética.

Lukács, Bloch, Brecht, Benjamin e Adorno. São Paulo, 1991. Dissertação de Mestrado em Filosofia (FFLCH - USP)

MARX, Karl. La Mercancía. In: El Capital. Buenos Aires: Siglo XXI Editores, 2002.

\section{Notas}

1 A emancipação da dissonância consiste, grosso modo, no uso livre de intervalos harmônicos dissonantes. Na tonalidade, os intervalos dissonantes aparecem subordinados a consonâncias que o preparam e resolvem, enquanto os consonantes aparecem de maneira livre, sem necessidade de preparo e resolução. Uma vez emancipada, a dissonância passa a aparecer livre da consonância, isto é, sem preparo e sem resolução, como sendo ela mesma uma consonância. A respeito deste conceito, v. The Emancipation of the Dissonance (DAHLHAUS, 1990).

2 "O misterioso da forma de mercadoria consiste simplesmente em que esta reflete para os seres humanos os caracteres sociais de seu próprio trabalho como caracteres sociais dos produtos do próprio trabalho, como atributos naturais e sociais destes objetos e, por conseguinte, também a relação social dos produtores com respeito ao trabalho total como uma relação social entre objetos existente fora deles" (MARX, em 0 capital, citado por ADORNO, 2009, p.25).

3 A passacaglia é um tipo de composição musical constituida por uma frase melódica no baixo que se repete um certo número de vezes e sobre a qual as vozes mais agudas se movimentam, apresentando variações a cada repetição da frase do baixo. Esta frase é concluída através de um movimento cadencial cada vez que é apresentada.

4 Em seu Fundamentos da Composição Musical (SCHOENBERG, 1996), Arnold Schoenberg distingue as "pequenas formas" das "grandes formas". As primeiras são constituídas basicamente pelo contraste entre partes e incluem desde a forma ternária mais simples, em que cada parte é uma frase musical, até as mais complexas, como o "Minueto e Trio", em que cada uma das três partes já é uma forma ternária simples. As segundas, que incluem basicamente as formas "Sonata" e "Rondó-Sonata" são as que envolvem desenvolvimento e variação sobre os elementos apresentados, e não apenas contraste. As transições, retransições, desenvolvimentos (parte B da forma sonata), e codas desenvolvidas são partes que aparecem apenas nas grandes formas. Devido ao distanciamento tanto harmônico quanto motívico dos elementos iniciais, estas formas requerem um maior reforço na conclusão para re-estabelecer a tônica principal.

Philippe Curimbaba Freitas é graduado em filosofia pela FFLCH - USP (São Paulo, SP) e mestrando em estética musical pelo IA - UNESP (São Paulo, SP). Cursou composição musical na Universidad Católica Argentina (Buenos Aires, Argentina) e na Faculdade de Artes Santa Marcelina (São Paulo, SP). 